\title{
THE
}

\section{WTP for Water Filters and Water Quality Testing Services in Guatemala}

Todd Guilfoos

University of Rhode Island, guilfoos@uri.edu

Sarah Hayden

University of Rhode Island

Emi Uchida

University of Rhode Island, euchida@uri.edu

Vinka Oyanedel-Craver

University of Rhode Island, craver@uri.edu

Follow this and additional works at: https://digitalcommons.uri.edu/enre_facpubs

The University of Rhode Island Faculty have made this article openly available.

Please let us know how Open Access to this research benefits you.

This is a pre-publication author manuscript of the final, published article.

Terms of Use

This article is made available under the terms and conditions applicable towards Open Access Policy Articles, as set forth in our Terms of Use.

\section{Citation/Publisher Attribution}

Guilfoos, T., Hayden, S., Uchida, E., \& Oyanedel-Craver, V. (2020). WTP for water filters and water quality testing services in Guatemala. Water Resources and Economics, 32, 100139. doi: 10.1016/ j.wre.2019.01.005

Available at: https://doi.org/10.1016/j.wre.2019.01.005

This Article is brought to you for free and open access by the Environmental and Natural Resource Economics at DigitalCommons@URI. It has been accepted for inclusion in Environmental and Natural Resource Economics Faculty Publications by an authorized administrator of DigitalCommons@URI. For more information, please contact digitalcommons-group@uri.edu. 


\section{WTP for Water Filters and Water Quality Testing Services in Guatemala}

Todd Guilfoos $^{1 *}$, Sarah Hayden ${ }^{1}$, Emi Uchida ${ }^{1}$, Vinka Oyanedel Craver ${ }^{2}$

We conduct a contingent valuation study to estimate the willingness to pay for a point-of-use water quality technology and water quality testing services in the highlands of Guatemala. This study is unique in two ways: we measure drinking water quality at the household level through water samples collected at the household and we elicit the willingness to pay for water quality testing services. We find a significant divergence in subjects' perceptions of water quality and the measured bacteria counts in their household water. This divergence is economically important as perceptions may play a significant role in willingness to pay for water quality improvements.

Keywords: Contingent valuation, water quality, water quality testing, willingness to pay.

\footnotetext{
${ }^{1}$ Department of Environmental and Natural Resource Economics, University of Rhode Island, Kingston, RI.

* Contact: guilfoos@uri.edu

${ }^{2}$ Department of Civil and Environmental Engineering, University of Rhode Island, Kingston, RI.
} 


\section{WTP for Water Filters and Water Quality Testing Services in Guatemala}

\section{Introduction}

Water quality and drinking water infrastructure are key to the health and development of society. These basic aspects of water security are a continuous struggle in many poor communities that lack the ability or means to obtain clean water and sanitation systems. Approximately 2.1 billion people lack access to safe drinking water (WHO and UNICEF, 2017). This lack of safe drinking water and poor hygiene leads to the spreading of waterborne diseases, diminishing the health and productivity of these communities. Exposure to contaminated water increases risks of diarrhea and cholera (Gundry et al., 2004), reduces the ability to work, and increases risks of impairments to child development.

The economic literature on water quality in developing countries has focused on the willingness-to-pay (WTP) for access to clean water. In a meta-study, Van Houtven et al. (2017) demonstrate a WTP of between $\$ 3$ and $\$ 30$ per month for increased access to clean water in developing countries. McConnell and Rosado (2000) use defensive expenditures in Espirito Santo, Brazil to estimate the WTP for safer water through filters, boiling, and bottled water and find that people are willing to pay $\$ 3$ per month on average for riskless water. Vásquez et al. (2009) find modest demand for subjects to gain access to safe water in Parro, Mexico; subjects are willing to pay an equivalent of an increase of $2 \%$ to $7 \%$ of their current water bill. These studies are primarily concerned with improving connectivity of water services and gaining access to treated water, in essence by connecting to a new or different source of water which is assumed to be more reliable and cleaner than the existing water supply. There are fewer studies evaluating a change in water quality in developing countries using point-of-use technologies. Point-of-use 
technologies (e.g., water filters, chlorine tablets, etc.) are ready and available to implement at the household level, and in some cases are the only option for developing communities to improve their water quality when centralized treatment systems are not economically or technically feasible (Thomas et al., 2013). We build on this literature by valuing demand for water filters and by recovering measures of water quality at the household level when administering the survey.

Information about the demand and usage of point-of-use water technology is lacking. In developing communities there is a lack of proper monitoring systems and capacity for water projects (Thomas et al., 2013). Monitoring usage and performance of point-of-use water technologies in low-income communities with poor infrastructure is especially challenging. Technology usage is usually self-reported by consumers and collected through in-person surveys or by phone (Almeida, G., et al, 2016). Information about performance, in terms of pollutant removal, are collected sporadically by trained personnel through home visits (Lambrou, T.P., et al, 2010). Additionally, most communities do not have analytical facilities to test water quality, and therefore rely on scarce visits from health centers or international aid organizations, if at all. In the context of point-of-use water treatment technologies used in developing communities, enhancing monitoring capacity as well as training personnel to analyze sampled water is essential for long-term performance assessment of these technologies, rather than relying on self-reported usage through surveys and sporadic performance assessment (e.g., intermittent sampling campaigns).

In addition to estimating the demand for water filters, we also assess the willingness to pay for water quality testing services. Water quality testing is becoming an increasingly important step in developing countries as water quality infrastructure in these communities is 
expanded. This second valuation question attempts to understand if the information about household level water quality is of significant value to households. Households that feel they understand their current water quality status would likely not have a significant willingness to pay for these services. Previous studies have shown information about water purification products can be important to adoption in developing countries (Ashraf et al. 2013), and water quality testing services may provide valuable supplementary information for cost-effective water treatment options in these communities. We are not aware of any other studies that estimate the value of water quality information in developing countries.

Information about water quality conditions can be important for stakeholders and researchers alike. Whittington and Pattanayak (2015) state that one of the key challenges in estimating the value of water quality improvements in developing communities is understanding the perceived benefits to a household ex-ante and how these perceptions compare to actual changes in water quality provided. Not all households in a community face the same risk of contaminated water. Low levels of enforcement to avoid contamination in developing countries can lead to heterogeneity in water quality within a community and lead to heterogeneity in exposure to bacteria contamination. From the researcher's perspective, it is unclear what the objective risk of waterborne disease in the household is and therefore the benefit of adopting a particular water treatment option is uncertain. A previous study performed in the highlands of Guatemala showed that a poorly maintained gravity-fed water distribution system in a mountain community created heterogeneity in water quality, with a low concentration of potentially pathogenic microorganisms in households close to the water source (between 1 to $5 \mathrm{cfu} / 100 \mathrm{ml}$ ) to very poor water quality in households located in the lower part of the city and far from the water source (up to $1000 \mathrm{cfu} / 100 \mathrm{~mL}$ ) (Kallman, et al., 2011). Current water quality conditions 
could be important to understanding the willingness to pay for and adopt new technologies for improving water quality. We make a specific contribution to this challenge by being able to compare actual household measurements of water quality to a stated level of current water quality and use these in the estimated demand for WTP for water quality goods and services. During our survey, enumerators take samples of the household water at the tap and test the samples for the presence of fecal coliform at a local water quality laboratory. This step allows us to measure the discrepancy between perceived and actual water quality and incorporate these measurements into the estimates of the willingness to pay for a point-of-use technology (e.g., water filter) and water testing services. Any disconnect between actual and perceived water quality measures may have important implications for behavior in these communities as households may under or over compensate with mitigation strategies to obtain cleaner water.

One challenge in estimating WTP for risk averting behavior is its endogeneity with risk perceptions. Previous studies point to the potential endogeneity of WTP and perceived quality due to unobserved heterogeneity (e.g., Whitehead 2006). Perceived quality may be affected by the same unobserved characteristics that influence willingness to pay, such as unobserved preferences, thereby biasing the coefficient on the perceived quality variable. A growing literature on health risk perceptions and risk averting behavior suggests that these are determined simultaneously (Lanz and Provins, 2017; Lloyd-Smith et al., 2018; Konishi and Adachi, 2011). Perceptions are sometimes used as independent variables in explaining risk averting behavior (or willingness to pay for such behavior) and are thought to reflect behavior better than objective measures. Although this raises an issue of simultaneous determination of consumption choices, such as how much bottled water to purchase and the formation of water quality perceptions, we have a setting in which the two non-market goods the subjects are asked to value (i.e., water 
filters and water quality testing service) are not currently available choices for the subject pool, and hence do not have the ability to influence water quality perceptions in the survey. Another concern is that there are omitted variables that are correlated with water quality perceptions as well as the error term in a willingness to pay regression equation. Variables related to health outcomes may lead to an endogeneity problem. While we do control for variables such as the number of diarrhea cases in households and water treatment practices, we cannot eliminate the possibility of endogeneity of water quality perceptions.

We find a mean willingness to pay of Q135 (Quetzal) (USD \$18.5) for a water filter and Q60 (USD \$8.2) for monthly water quality testing services. Subject's water perceptions affect the willingness to pay for a water filter as subjects with the perception of "very clean" drinking water have close to a zero willingness to pay for a water filter. In addition, we find perceptions of water quality do not correlate with the measure of fecal coliform or total coliform from the samples of water taken at the households. The divergence in perceptions and actual risks suggests that information about water quality and risks borne at the household level is important to behavior. This finding highlights a particular policy concern - if households are unaware of their own water quality, they may significantly undervalue important water quality projects that are welfare enhancing.

Our paper proceeds as follows: in Section 2 we discuss the village in Guatemala in which the survey was given; in Section 3 we discuss the design and implementation of the survey; Section 4 describes the data; Section 5 presents the econometric results and estimates of willingness to pay, and Section 6 concludes.

\section{Study Area}


San Mateo Ixtatán is located in the northwestern highlands of Guatemala. It has an approximate population of 39,000 (INE, 2013), of which 54\% are of Mayan descent (national average 38\%), $54 \%$ are illiterate, and more than $90 \%$ live in poverty (CEDFOG, 2008). The main economic activities in the town are agriculture, retail, and craftsmanship (Consejo Municipal de Desarrollo, 2010). The community has a spring-fed water distribution system that connects distribution tanks to each home, but there is no water or wastewater treatment infrastructure. Water quality is a concern: a study in 2011 found that the concentration of Escherichia coli is high in this community, increasing from the distribution tank to the residential point of consumption (Kallman et al. 2011). Only one out of six distribution tanks met the World Health Organization (2015) (WHO) standard of less than $1 \mathrm{cfu} / 100 \mathrm{~mL}$, while the average for all neighborhoods greatly exceeded this threshold $(\mathrm{mean}=224 \mathrm{cfu} / 100 \mathrm{~mL})$. The heavily deteriorated water distribution infrastructure and the lack of proper sanitation are the major causes of contamination in the drinking water system. These factors led to endemic cases of gastrointestinal diseases in the community and suggest that a centralized treatment system alone may not be as effective as a point-of-use technology due to the risk of recontamination in the distribution system.

All households in our sample have piped water in or near their homes. A previous survey conducted in the same community revealed that the majority of households store water in cooking pots or access the tap as needed, and most households treat their drinking water by boiling. ${ }^{1}$ When asked why users boil their water, the primary responses were to improve health, prevent illness, and kill bacteria. Water samples were taken at homes, and although many houses boiled water prior to their samples being tested all of the water samples contained coliform bacteria exceeding the WHO standard (mean $=63.76 \mathrm{cfu} / 100 \mathrm{~mL}) .72 \%$ of

\footnotetext{
${ }^{1}$ The previous survey is from unpublished work by members of this team from 2010.
} 
respondents washed their hands after using the latrine, 92\% washed their hands before eating, and $66 \%$ washed their hands before cooking. One of the deterrents to washing after going to the bathroom was the proximity of water and soap to the latrine. Of the households surveyed, only 14 out of 64 had hand-washing facilities near their latrine. These practices and the current water supply system demonstrate the significant risk of waterborne disease to this community.

To help improve water quality infrastructure and to reduce waterborne disease risks, a water quality laboratory was built in 2016 in the region of Huehetenango, where San Mateo Ixtatán is located. The water quality laboratory was implemented with the support of several organizations (University of Rhode Island-Engineers for a Sustainable World, RambollEnviron Foundation, University of Rhode Island College of Engineering and the Ixtatán Foundation), and is the first in the northern region of Huehetenango. Water samples taken from households in this study were tested for fecal coliform bacteria and total coliform bacteria at this laboratory. At the time of the survey the water lab did not offer testing services for households.

\section{Survey Design and Implementation}

In March 2017, we implemented a household survey with 101 randomly-selected households in San Mateo Ixtatán, Guatemala to elicit willingness to pay for water filters and monthly water quality testing. At the conclusion of the survey, water samples were taken at the tap and then taken to the local water quality laboratory for analysis.

The households were selected through a geographical random sampling strategy (Figure 1). Specifically, the sampling frame was comprised of all homes in the town of San Mateo Ixtatán. Using aerial maps of the town, we first randomly selected 101 latitude and longitude 
coordinates and the enumerators located the homes in the field, choosing the closest home to the randomly selected point. Households were asked to participate in a short survey and whether the enumerator could take a sample of their drinking water at the tap which services their home. Surveyed households were not provided with compensation. If a household chose not to participate in the survey, or no one was home, a neighboring home was used as an alternate sample. ${ }^{2}$ All homes surveyed had piped water service at or near the home. At the end of the survey, the water sample was collected and delivered to the local water quality testing lab.

Figure 1 illustrates the study area, the distribution of surveyed households and their water quality measurements, the location of the water tanks, and the location of the water quality testing lab.

The survey implementation and water quality testing were done with the assistance of a local nonprofit group, the Ixtatán Foundation. The surveys were administered orally in Spanish by trained graduate and undergraduate student enumerators. ${ }^{3}$ Some residents in San Mateo speak Spanish and some speak a local Mayan dialect, Chuj. Each enumerator was accompanied by a local volunteer (high school student) fluent in Chuj.

The valuation questions in this survey rely on a simple referendum design in which we describe the product which is being offered to the subjects with a stated price and they respond whether they are willing to purchase this product with a yes or no answer. By varying the price among the subjects, we can estimate a demand curve and a willingness to pay for the products described. Specifically, we use three price points which were randomly assigned to the households surveyed to estimate demand for two goods. We value the willingness to pay for a water filter, a point-of-use water quality technology which provides benefits to households

\footnotetext{
${ }^{2}$ Few households declined to be interviewed.

${ }^{3}$ These students traveled from their university campus to conduct this research under the supervision of a faculty member. The enumerators were trained in human subjects research.
} 
through reducing exposure to bacteria. We also value monthly water quality testing services. The price points used to value these goods in the local currency Guatemalan Quetzal (Q) are Q30 (USD \$4), Q75 (USD \$10), and Q150 (USD \$20). Prices are based on the full estimated cost of providing the products locally and just happen to be identical for both the water quality treatment device (filter) and for monthly water quality testing services. These two water quality goods are not available on the market, so there are no market prices available. There are some places where filters are being sold elsewhere in the country but not in this village. Often filters are provided by NGOs in similar rural areas and not sold directly to consumers. The water testing service is a new product which has not been offered previously and our study is the first to estimate a value for it in a developing country context as far as we are aware.

Hypothetical bias is a large concern in the contingent valuation literature (Murphy et al., 2005; Loomis, 2011). It is believed that surveyed responses without a payment mechanism may be inflated because the responses are a hypothetical construct, especially when the subjects are unfamiliar with the goods and services in which they are being asked to value. The literature also suggests that not all nonmarket assets have a fixed markup due to the hypothetical bias, so it is not advisable to take a percentage of the willingness to pay to adjust for hypothetical bias for policy purposes. In addition to the willingness to pay for water quality related goods, we also use a follow-up question protocol to control for hypothetical bias. The follow up question follows Blumenschein et al. (2008) and asks whether the respondent was "Definitely Sure" of their response to a contingent valuation question. The authors found when using only the "Definitely Sure" sample of responses, the estimates of WTP were found to be consistent with a field experiment elicitation for the same good. Therefore, they conclude that utilizing the follow-up question is a simple and cheap way to help correct for hypothetical bias in a contingent valuation 
survey. In the next two subsections, we provide the descriptions of the water quality products offered, the referendum question, and the follow-up question to control for hypothetical bias.

\subsection{Valuation Question for Water Quality Improvement}

The statements in italics below were read to the respondents in Spanish or Chuj by enumerators or their translators which elicited a response of whether or not the respondent would purchase a water filter at a specific price.

\section{Water Quality Treatment Device Description:}

Treating your drinking water can provide many health benefits to the household. When your water quality is bad the household may be exposed to water borne diseases such as diarrhea. A water filter that treats water removes up to $99.99 \%$ (if properly used) of bacteria which can reduce the number of times household members get diarrhea, up to $80 \%$ (range 50-80\%). For example, if you experience diarrhea 10 times a month, using a filter may reduce the number of times you experience diarrhea to 2 times a month, as shown in the Figure below.

Number of Diarrhea Cases in a Month 


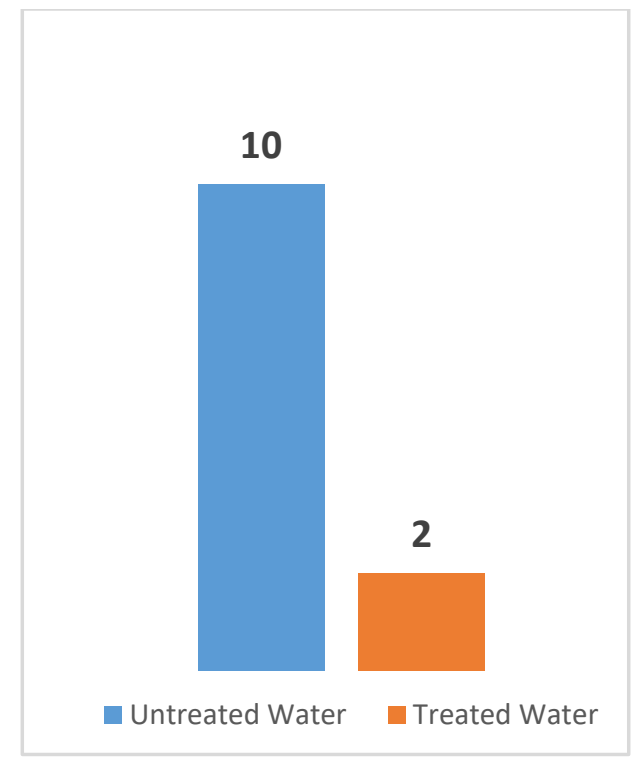

This water filter is easy to use and maintain and works by removing the bacteria from the water. Several episodes of diarrhea in a month can cause dehydration in children and affect their growth and development.

Assume that your household is being offered the opportunity to purchase the water filter that was just described to you. The water filter would be provided for one-time fee. Assume that if you choose to purchase the water filter you would have to use some of your household income to pay here and now with cash, cheque or credit card. Would your household buy this water filter here and now at a price of Q150? Please circle your answer below.

Yes No 
Are you 'probably sure' or 'definitely sure' that your household would (not) buy the water filter here and now at a price of RD150? Please circle your answer below.

Probably sure

Definitely sure

The framing of this question focuses the valuation on the health aspects of the water filter. We provide the specific mechanism (water filter) to make the question more realistic to subjects. A difference from other contingent valuation questions is that our implied lower risk level still assumes that after the adoption of a water filter, there still are risks of waterborne diseases, which is true of most point-of-use technologies. Many other studies ask for a WTP for a risk-free option in an attempt at understanding the policy option of a centralized water distribution treatment system. Our estimate should provide a lower bound for a completely risk-free option of water quality improvement.

\subsection{Valuation Question for Water Quality Testing}

The statements in italics below were read to the respondents in Spanish or Chuj by enumerators or their translators which elicited a response of whether or not the respondent would purchase a monthly water quality testing services at a specific price. 


\section{Water Quality Testing Service Description:}

A local water service provides twice a month water testing for bacteria and nitrate related with water quality problems. The tests can identify if your drinking water has problems with bacteria or nitrates. Bacteria in contaminated water can cause diarrhea and other stomach diseases. Nitrates can affect the growth and development of children. In this program, a service member from the local water service will come to your home twice a month to take water samples to be processed at a laboratory and you will be notified by telephone or by a personal visit of the results after each test. Additionally, this service provides advice and support to your household if the water quality is bad.

Assume that your household is being offered the opportunity to purchase the water quality testing service that was just described to you. All of the services that were described to you would be provided for one flat rate per month. Your household could renew or cancel this service each month. Assume that if your household chose to purchase the service, you would have to use some of your household income to pay here and now with cash, cheque or credit card. Would your household buy this service here and now at a price of Q150? Please circle your answer below.

Yes No 
Are you 'probably sure' or 'definitely sure' that your household would (not) buy the water quality testing service here and now at a price of Q150? Please circle your answer below.

Probably sure

Definitely sure

The development of this question is based on the water quality testing facilities that were recently built in Guatemala to provide water quality information to the communities. At this point, the services are so new that it is unclear in the long run how they will be financed and at what prices the services will be charged. This study will likely provide a useful input into the development of these water quality labs in the future.

The ordering of the two valuation questions in the survey were not randomized. Therefore, the particular order of the questions may have an effect on responses, although we do not know the direction of potential bias.

\section{Data}

We collected 101 complete surveys from households. After eliminating 6 households for nonresponses to critical questions, we conducted the analyses with 95 complete surveys (see Table 1 for descriptive statistics). In addition to the willingness to pay and the follow-up bias control questions, we ask for demographic information, water quality perceptions, health status, water treatment practices, and water quality measurements.

We find some systematic differences between households that are "Definitely sure" versus "Probably sure" of their decisions to purchase the water filter or the water quality testing service (Table 2). We find that when the survey takers are the heads of the households, they are 
more sure of their answers, presumably reflecting more confidence in making decisions for the household. This finding indicates that there is a potential form of hypothetical bias depending on the role the survey respondent takes in the household as a decision maker. We also find that more households are involved in treating their water through boiling who are "Definitely sure" of their answers.

\section{Results}

Of 95 households, $58.9 \%$ responded that they are willing to purchase the water filter while $45.2 \%$ responded that they are willing to purchase the water quality testing services. To analyze these outcomes, we use a logit model to measure the effect of price on the probability of purchasing either good. We estimate the following model:

$$
\operatorname{Pr}\left(Y_{i}=1\right)=P_{i} * \beta+X_{i} \delta+\varepsilon_{i}
$$

where $Y_{i}=1$ if subject $i$ responds yes to the purchase of the good at price $P_{i}$ and $X_{i}$ is a vector of other explanatory variables.

As expected, we find that a higher price of both goods leads to a lower probability of purchasing a water filter (Table 3, column 1) and water quality testing services (column 3). When we analyze the results using the subsample of responses in which subjects are "Definitely sure," we find similar results (columns 2 and 4).

\section{Estimates of Willingness to Pay}

We estimate the mean willingness to pay with a parametric method using equation (2): 


$$
W T P=-\frac{\ln \left(1+e^{\delta}\right)}{\beta} .
$$

$\beta$ is the coefficient on price and $\delta$ is the regression constant from the results of equation (1). The constant term is fixed at the means of all the covariates, excluding the price variable. This method estimates the area below the demand curve and provides a restriction that willingness to pay be non-negative (Johanssan 2003; Blumenschein et al 2008). Underlying this formula is the presumption of a random utility model with a linearly additive utility function, which is common in the discrete choice literature.

The mean willingness to pay for a water filter of respondents that are "Definitely sure" of their response is Q135 (USD \$18) (Table 4, column 2), which translates to at least 5\% of monthly income for a majority of respondents. ${ }^{4}$ The mean willingness to pay for monthly water quality testing services of respondents that are "Definitely sure" of their response is Q60 (USD \$8) (Table 4, column 4), which is a much smaller figure than the WTP for a water filter. We find there is more hypothetical bias in the responses to monthly water quality testing services than for water quality improvements, evidenced by the difference of WTP by using the subsample of respondents who are "Definitely sure" of their responses in Table $4 .{ }^{5}$ This may be because respondents are less familiar with water testing services than water filters, which may pose a challenge to subjects about how sure they are in their responses, therefore deflating the willingness to pay for water testing services. A water filter is a product with defined and direct benefits for water quality, while the testing service is something with more ambiguity as to its

\footnotetext{
${ }^{4}$ This is calculated based on the observation that most of the subjects responded to a survey question for monthly income at below Q2,500. This variable is left out of the regression analysis since there was so little variation in responses.

${ }^{5}$ We find similar results of WTP when including the full sample but using a binary control for a "Definitely Sure" response and interacting it with Price. These can be found in the appendix in Table 3A.
} 
benefits. Previous studies suggest that hypothetical bias is not constant across subjects and many goods may not have significant bias (Murphy et al., 2005). Because of these reasons, we suggest that the WTP estimates based on "Definitely Sure" sample be used for policy applications (e.g., in a cost benefit analysis.) We include an additional specification in the Appendix (Table 5A) which uses "Definitely Sure" as a covariate with the full sample of observations and obtain qualitatively and quantitatively the same result as using the subsample. ${ }^{6}$

Additionally, we estimate the mean willingness to pay for a water filter by subjects with "very clean" perceptions of drinking water quality. ${ }^{7}$ This estimate is constructed using a constant term, $\delta$, fixed at the means of all the covariates except water quality perceptions, which is populated for a subject with "very clean" water quality perceptions. The estimates in Table 5 show that subjects who believe they have "very clean" water would not buy a filter because their willingness to pay is close to zero. This is sensible from the perspective of the subject if they are correct about their perceptions of water quality. The perceptions of water quality are likely more important that actual water quality measurements when households are unaware of the objective measures, and this result hints at a larger issue in how to accurately measure perceptions. We have used a simple categorization to elicit the perceived water quality for simplicity, though it is worth investigating how robust this decrease in the WTP is associated with water quality perceptions. For instance, what factors (ex. taste, clear water, smell, bacteria count) are the most important to have perceived 'good' water quality? Are these perceptions related to health issues and how aware are the households of the link between water quality, hygiene, and

\footnotetext{
${ }^{6} \mathrm{We}$ view the subsample as being more robust because it allows the coefficients of all co-variates to be different between samples.

${ }^{7}$ We also interacted Very High Water Quality Perceptions with Price and find insignificant coefficients, reported in the Appendix Table 2A. We are somewhat limited in analyzing the heterogeneity of our sample and the hypothetical bias due to the smaller sample size and collinearity of covariates as additional controls are added to the model.
} 
gastrointestinal illness? These are all important mechanisms that may affect the WTP for water quality improvements.

In response to potential concerns about endogeneity of water quality perceptions and replies to the willingness to pay question, we estimate a Two-Stage Residual Inclusion (2SRI) model that uses the distance to the nearest water tank as an instrumental variable (Appendix Table 4B). It appears that this instrument is weak and does not provide much clarity to our estimate because 1) the first-stage regression does not show strong correlation between the instrument and water quality perception; and 2) estimates are rather imprecise and may violate the non-exclusion condition.

Figure 2 and Table 6 shows the relationship between actual measurements of fecal coliform and water quality perceptions of our subjects. Although a priori we expect that objective measures of water quality to be correlated with perceptions of water quality, we do not find much evidence of that in this study. There are multiple reasons why water quality perceptions may be different than the objective measures gathered through our tested water samples. Households lack information about the risks to the water supply and therefore people are mistaken about the water quality they face. We found through the field observations prior to the survey that many people in this community do not have any water quality information which may lead to this disparity. Another potential reason is that our survey does not capture the risk to water quality in the way that subjects think about water quality. Finally, since our objective measure of risk was based on one-time sampling, there may be discrepancies with historical trends in water quality that shape perceived risks. Long term risks may vary overtime with storm events and the quality of the supply lines to households. This result suggests a major policy challenge and potential role in the placement of water quality testing labs in developing 
communities. The fact that subjects are mistaken about their own water quality may be an important reason why water quality technologies are undervalued. As mentioned previously, further research is needed to assess the causal mechanisms at play because our measure of water quality perceptions may be endogenous. If at-risk communities can better understand their exposure to bacteria and the relationship to health outcomes, it may significantly increase their willingness to pay for point-of-use water quality technology.

In regards to water quality perceptions and health outcomes, there is a weak relationship between the two in our survey results. Figure 3 and Table 6 shows the slight decrease in reported diarrhea cases per person by household as perceptions of water quality become cleaner. But as our results show in Table 3, more cases of household diarrhea do not have a statistically significant effect on the willingness to pay for a water filter or water quality testing. We view the link between health and WTP for water quality improvements as weakly related from this evidence.

Our sample and results are most representative of a small to medium size, impoverished rural village in Guatemala without a centralized water treatment system. It may be more difficult to generalize our results to situations with better centralized distribution systems as well as areas that are more populated as they may face different water contamination risks.

\section{Conclusion}

Poor adoption rates and low demand for point-of-use water technologies, such as water filters, puzzle many researchers, as the benefits seem to outweigh the small costs for such technologies in the developing world. In our study, we attempt to gain more insight into this dilemma. 
Through the use of a referendum question, we estimate the willingness to pay for water filters and water quality testing services in order to understand the value for low-cost water quality infrastructure improvements. We also obtain drinking water samples from each surveyed household to provide objective measures of water quality at the tap in order to understand the risks that households face and how the measures relate to the subject's perceived water quality. We find that one reason that there may be a low demand for such technologies is subject's beliefs that their water is cleaner than objective measures suggest. At the very least it is a concern that there is a divergence between subjective and objective measures of health risks in the community.

We find a mean willingness to pay for water filters of \$18 USD for the general population and an estimate close to zero for subjects with a perceived water quality of "very clean", though the measure of water quality perceptions may be endogenous due to omitted variables related to health risks. We find that perceptions of water quality deviate from objective measures of water quality, with significant bacteria measurements being present in households with "very clean" perceived water quality. Estimates of demand for monthly water quality testing services are $\$ 8$ USD and hold a substantial hypothetical bias. The estimates are in the range of willingness to pay for clean water estimates found in previous studies.

The results of this study suggest that efforts to supplement knowledge of water quality through testing may be an important aspect to help in the adoption of point-of-use technologies since water quality perceptions are not correlated with measured bacteria counts. In addition, there may be room to improve knowledge of the links between exposure to contaminated water and gastrointestinal illnesses. 
It may not be feasible or desirable to connect much of the 700 million people in need of cleaner water to comprehensively treated water and sanitation services, making point-of-use technologies an important tool to improve water quality and reduce exposure to waterborne diseases. Further work on water quality information and behavior is needed to understand the impact of water quality information when water quality testing is available in developing communities. Water quality information may give households specific mitigation strategies that are customized for their budget and risk profiles, which could affect adoption of point-of-use technologies. As different types of household water quality services, such as water quality labs, are developed, other questions may be critical in understanding the gap in water quality knowledge and how to present this information effectively to communities.

\section{References}

Almeida, G., Vieira, J., Sá Marques, A., Cardoso, A., \& Ludwig, O. (2016). Identifying Household Water Use through Transient Signal Classification. Journal of Computing in Civil Engineering. 30(2): 04015007.

Ashraf, N., Jack, B. K., \& Kamenica, E. (2013). Information and subsidies: Complements or substitutes?. Journal of Economic Behavior \& Organization, 88, 133-139.

Blumenschein, K., Blomquist, G. C., Johannesson, M., Horn, N., \& Freeman, P. (2008). Eliciting willingness to pay without bias: evidence from a field experiment. The Economic Journal, 118(525), 114-137.

Centro de Estudios y Documentación de la Frontera Occidental de Guatemala- CDDFOG (2008) Huehuetenango en Cifras, Ciudad de Guatemala, Guatemala.

Consejo Municipal de Desarrollo (2010) Plan de Desarrollo San Mateo Ixtatan, Huehuetenango. Municipio de San Mateo Ixtatan, Huehuetenango, Guatemala.

Gundry, S., Wright, J., \& Conroy, R. (2004). A systematic review of the health outcomes related to household water quality in developing countries. Journal of water and Health, 2(1):1-13.

Johansson, P-O. (1995). Evaluating Health Risks: An Economic Approach, Cambridge: Cambridge University Press. 
Kallman, E., Oyanedel-Craver, V., and Smith, J. (2011). Ceramic filters impregnated with silver nanoparticles for point-of-use water treatment in rural Guatemala. Journal of Environmental Engineering, 137(6): 407-415.

Konishi, Y., \& Adachi, K. (2011). A framework for estimating willingness-to-pay to avoid endogenous environmental risks. Resource and Energy Economics, 33(1), 130-154.

Lambrou, T.P., C.C. Anastasiou, and C.G. Panayiotou, A. (2010). Nephelometric Turbidity System for Monitoring Residential Drinking Water Quality, in Sensor Applications, Experimentation, and Logistics, N. Komninos, Editor. p. 43-+.

Lanz, B., \& Provins, A. (2017). Using averting expenditures to estimate the demand for public goods: Combining objective and perceived quality. Resource and Energy Economics, 47, 20-35.

Lloyd-Smith, P., Schram, C., Adamowicz, W., \& Dupont, D. (2018). Endogeneity of risk perceptions in averting behavior models. Environmental and Resource Economics, 69(2), 217 246.

Loomis, J. (2011). What's to know about hypothetical bias in stated preference valuation studies?. Journal of Economic Surveys, 25(2): 363-370.

McConnell, K. E., and Rosado, M.A. (2000). Valuing discrete improvements in drinking water quality through revealed preferences. Water Resources Research 36.6: 1575-1582.

Murphy, J. J., Allen, P. G., Stevens, T. H., \& Weatherhead, D. (2005). A meta-analysis of hypothetical bias in stated preference valuation. Environmental and Resource Economics, 30(3): 313-325.

Thomas, E. A., Barstow, C. K., Rosa, G., Majorin, F., \& Clasen, T. (2013). Use of Remotely Reporting Electronic Sensors for Assessing Use of Water Filters and Cookstoves in Rwanda. Environmental Science \& Technology. 47(23): 13602-13610.

Van Houtven, G. L., Pattanayak, S. K., Usmani, F., \& Yang, J. C. (2017). What are households willing to pay for improved water access? Results from a meta-analysis. Ecological Economics 136: 126-135.

Vásquez, W. F., Mozumder, P., Hernández-Arce, J., \& Berrens, R. P. (2009). Willingness to pay for safe drinking water: Evidence from Parral, Mexico. Journal of Environmental Management 90.11: 3391-3400.

Whitehead, J. C. (2006). Improving willingness to pay estimates for quality improvements through joint estimation with quality perceptions. Southern Economic Journal, 100-111. 
Whittington, D., \& Pattanayak, S. K. (2015). Water and sanitation economics: reflections on application to developing economies. by A. Dinar and K. Schwabe, Edward Elgar Publishing, 469-499.

World Health Organization. (2015). Progress on sanitation and drinking water: 2015 update and MDG assessment. World Health Organization.

WHO and UNICEF (2017) Progress on Drinking Water, Sanitation and Hygiene: 2017 Update and SDG Baselines. Geneva: World Health Organization (WHO) and the United Nations Children's Fund (UNICEF), Licence: CC BY-NC-SA 3.0 IGO. 


\section{Tables and Figures}

Table 1. Descriptive Statistics

\begin{tabular}{|c|c|c|}
\hline Variable & Mean & Standard Deviation \\
\hline \multicolumn{3}{|l|}{ Household Characteristics } \\
\hline \# of members in household & 6.271 & 2.438 \\
\hline Respondent is head of household ( $1=$ Yes) & 0.421 & 0.496 \\
\hline No education & 0.136 & 0.345 \\
\hline Primary education & 0.368 & 0.484 \\
\hline Middle school education & 0.210 & 0.409 \\
\hline Secondary school education & 0.126 & 0.333 \\
\hline Post-secondary school education & 0.157 & 0.366 \\
\hline Respondent is female ( $1=$ Yes $)$ & 0.778 & 0.417 \\
\hline Age & 39.315 & 15.729 \\
\hline \multicolumn{3}{|l|}{ Water Treatment } \\
\hline Boil water & 0.810 & 0.393 \\
\hline \multicolumn{3}{|l|}{ Water Quality Perceptions } \\
\hline Uncertain about water quality & 0.347 & 0.478 \\
\hline Very dirty water quality & 0.031 & 0.175 \\
\hline Dirty water quality & 0.126 & 0.333 \\
\hline Clean water quality & 0.421 & 0.496 \\
\hline Very clean water quality & 0.073 & 0.262 \\
\hline \multicolumn{3}{|l|}{ Water Quality Measurements } \\
\hline Fecal coliform cfu/100 mL & 44.736 & 104.821 \\
\hline Total coliform cfu/100 mL & 77.357 & 140.067 \\
\hline \multicolumn{3}{|l|}{ Health } \\
\hline \# cases of diarrhea per person & 0.192 & 0.316 \\
\hline \multicolumn{3}{|l|}{ Water Quality Valuation Questions } \\
\hline Yes to Filter & 0.589 & 0.494 \\
\hline Definitely Sure Response (Filter) & 0.515 & 0.502 \\
\hline
\end{tabular}


Yes to Water Test

Definitely Sure Response (Water Test)
0.452

0.500

0.494

Notes: $N=95$. 
Table 2. Sample Differences by Definitely Sure and Probably Sure Responses

\begin{tabular}{|c|c|c|c|c|c|c|}
\hline & (1) & (2) & (3) & (4) & (5) & (6) \\
\hline & $\begin{array}{c}\text { Definitely } \\
\text { Sure For } \\
\text { Filter }\end{array}$ & $\begin{array}{c}\text { Probably } \\
\text { Sure For } \\
\text { Filter }\end{array}$ & $\begin{array}{c}\text { Definitely } \\
\text { Sure For } \\
\text { Test }\end{array}$ & $\begin{array}{c}\text { Probably } \\
\text { Sure For } \\
\text { Test }\end{array}$ & $\begin{array}{c}\text { p-value } \\
\text { Definitely } \\
\text { vs. } \\
\text { Probably } \\
\text { Sure }\end{array}$ & $\begin{array}{c}\text { p-value } \\
\text { Definitely } \\
\text { vs. } \\
\text { Probably } \\
\text { Sure }\end{array}$ \\
\hline Variable & & & & & For Filter & For Test \\
\hline Observations & 49 & 46 & 56 & 39 & - & - \\
\hline \multicolumn{7}{|l|}{ Household Characteristics } \\
\hline \# in household & 6.122 & 6.434 & 6.214 & 6.358 & 0.535 & 0.777 \\
\hline Head of household & 0.510 & 0.326 & 0.500 & 0.307 & 0.070 & 0.062 \\
\hline No education & 0.122 & 0.152 & 0.125 & 0.153 & 0.677 & 0.691 \\
\hline Primary education & 0.428 & 0.304 & 0.428 & 0.282 & 0.213 & 0.148 \\
\hline Middle school education & 0.183 & 0.239 & 0.178 & 0.256 & 0.512 & 0.365 \\
\hline Secondary school education & 0.081 & 0.173 & 0.107 & 0.153 & 0.179 & 0.505 \\
\hline Post-secondary school ed. & 0.183 & 0.130 & 0.160 & 0.153 & 0.482 & 0.929 \\
\hline Female & 0.755 & 0.804 & 0.750 & 0.820 & 0.568 & 0.420 \\
\hline Age & 39.387 & 39.239 & 40.696 & 37.333 & 0.963 & 0.307 \\
\hline \multicolumn{7}{|l|}{ Water Treatment } \\
\hline Boil water & 0.897 & 0.717 & 0.875 & 0.717 & 0.025 & 0.055 \\
\hline \multicolumn{7}{|l|}{ Water Quality Perceptions } \\
\hline Uncertain & 0.326 & 0.369 & 0.321 & 0.384 & 0.663 & 0.529 \\
\hline Very dirty & 0.020 & 0.043 & 0.017 & 0.051 & 0.525 & 0.364 \\
\hline Dirty & 0.183 & 0.065 & 0.178 & 0.051 & 0.084 & 0.067 \\
\hline Clean & 0.408 & 0.434 & 0.411 & 0.435 & 0.795 & 0.809 \\
\hline Very Clean & 0.061 & 0.086 & 0.714 & 0.076 & 0.635 & 0.920 \\
\hline \multicolumn{7}{|l|}{ Water Quality Measurements } \\
\hline Fecal Coliform cfu/100 mL & 25.551 & 65.173 & 30.285 & 65.487 & 0.065 & 0.108 \\
\hline Total Coliform cfu/100 mL & 57.857 & 98.130 & 61.767 & 99.744 & 0.165 & 0.195 \\
\hline \multicolumn{7}{|l|}{ Health } \\
\hline \# cases of diarrhea per & 0.193 & 0.190 & 0.225 & 0.144 & 0.960 & 0.216 \\
\hline person & & & & & & \\
\hline
\end{tabular}


Table 3. Logit Regression Results

\begin{tabular}{|c|c|c|c|c|}
\hline & \multicolumn{2}{|c|}{ Water Filter } & \multicolumn{2}{|c|}{ Water Test } \\
\hline & $\begin{array}{l}\text { Full sample } \\
\text { (1) }\end{array}$ & $\begin{array}{l}\text { Definitely sure } \\
\text { subsample } \\
\text { (2) }\end{array}$ & $\begin{array}{l}\text { Full sample } \\
\text { (3) }\end{array}$ & $\begin{array}{c}\text { Definitely sure } \\
\text { subsample } \\
\text { (4) }\end{array}$ \\
\hline \multirow[t]{2}{*}{ Price } & $-0.013^{* *}$ & $-0.020^{*}$ & $-0.010^{*}$ & $-0.021 * *$ \\
\hline & $(2.26)$ & $(1.81)$ & $(1.95)$ & $(2.13)$ \\
\hline \multirow[t]{2}{*}{ \# in household } & 0.040 & -0.224 & 0.042 & -0.025 \\
\hline & $(0.33)$ & $(0.98)$ & $(0.39)$ & $(0.16)$ \\
\hline \multirow[t]{2}{*}{ Head of household } & -0.016 & 0.486 & -0.074 & -0.592 \\
\hline & $(0.03)$ & $(0.33)$ & $(0.13)$ & $(0.53)$ \\
\hline \multirow[t]{2}{*}{ Female } & $-1.532 *$ & $-3.016^{*}$ & -0.371 & 0.617 \\
\hline & $(1.94)$ & $(1.73)$ & $(0.58)$ & $(0.62)$ \\
\hline \multirow[t]{2}{*}{ Age } & -0.017 & -0.041 & -0.004 & 0.018 \\
\hline & $(0.87)$ & $(0.93)$ & $(0.20)$ & $(0.46)$ \\
\hline \multirow[t]{2}{*}{ Primary education } & 0.008 & 3.971 & -0.421 & 2.245 \\
\hline & $(0.01)$ & $(1.61)$ & $(0.50)$ & $(1.33)$ \\
\hline \multirow[t]{2}{*}{ Middle school ed. } & 0.334 & 4.408 & -0.367 & 0.026 \\
\hline & $(0.34)$ & $(1.55)$ & $(0.38)$ & $(0.01)$ \\
\hline \multirow[t]{2}{*}{ Secondary school ed. } & $2.346^{*}$ & $8.188 * *$ & 1.359 & $4.196 * *$ \\
\hline & $(1.90)$ & $(1.99)$ & $(1.29)$ & $(1.97)$ \\
\hline \multirow[t]{2}{*}{ Post-secondary school ed. } & 1.010 & $5.725^{* *}$ & 0.018 & $3.784 *$ \\
\hline & $(0.95)$ & $(2.04)$ & $(0.02)$ & $(1.84)$ \\
\hline \multicolumn{5}{|l|}{ Water Treatment } \\
\hline \multirow[t]{2}{*}{ Boil water } & 0.715 & -0.697 & -0.196 & -1.274 \\
\hline & $(0.99)$ & $(0.33)$ & $(0.31)$ & $(1.02)$ \\
\hline \multicolumn{5}{|l|}{ Water Quality Perceptions } \\
\hline \multirow[t]{2}{*}{ Very dirty } & -0.085 & - & - & - \\
\hline & $(0.06)$ & - & - & - \\
\hline Dirty & 0.346 & 2.345 & 1.150 & $2.987^{*}$ \\
\hline
\end{tabular}




\begin{tabular}{lcccc} 
& $(0.37)$ & $(1.31)$ & $(1.32)$ & $(1.78)$ \\
Clean & -0.021 & 0.352 & 0.644 & 0.848 \\
& $(0.03)$ & $(0.27)$ & $(1.13)$ & $(0.76)$ \\
Very clean & $-2.845^{* *}$ & $-4.167^{*}$ & 0.298 & -0.206 \\
& $(2.13)$ & $(1.68)$ & $(0.30)$ & $(0.13)$ \\
Health & $(0.95)$ & $(2.04)$ & $(0.02)$ & $(1.84)$ \\
\# cases of diarrhea per & -0.852 & -1.875 & -0.118 & 0.357 \\
person & $(1.02)$ & $(1.15)$ & $(0.14)$ & $(0.28)$ \\
Water Quality Measurement & & & \\
Fecal coliform & $-0.009^{* *}$ & -0.006 & -0.004 & -0.004 \\
& $(2.03)$ & $(0.60)$ & $(1.52)$ & $(0.78)$ \\
Constant & 2.794 & 4.275 & 0.880 & -1.495 \\
& $(1.53)$ & $(1.24)$ & $(0.54)$ & $(0.51)$ \\
\hline$N$ & 95 & 48 & 92 & 55 \\
\hline Pseudo R-squared & 0.2324 & 0.3893 & 0.1286 & 0.3722 \\
\hline
\end{tabular}

Note: $\mathrm{z}$-statistics are reported in brackets. $* * *, * *, *$ indicate statistical significance at the $1 \%, 5 \%$, and $10 \%$ level. 
Table 4. Mean Willingness to Pay (Currency: Quetzal)

\begin{tabular}{lcccc}
\hline & \multicolumn{2}{c}{ Water Filter } & \multicolumn{2}{c}{ Water testing service } \\
\hline & Full sample & $\begin{array}{l}\text { Definitely sure } \\
\text { subpopulation }\end{array}$ & Full sample & $\begin{array}{c}\text { Definitely sure } \\
\text { subpopulation }\end{array}$ \\
\hline Mean WTP & 133.00 & 134.95 & 107.50 & 60.31 \\
& $(30.88)$ & $(34.32)$ & $(30.94)$ & $(14.23)$ \\
\hline$N$ & 95 & 48 & 92 & 55 \\
\hline
\end{tabular}

Note: Standard errors in brackets. Estimates are based on logit regression results from corresponding columns in Table 3. 
Table 5. Mean WTP for Filter with Very Clean Perceived Water Quality

\begin{tabular}{lcc} 
& Full sample & $\begin{array}{c}\text { Definitely sure } \\
\text { subpopulation }\end{array}$ \\
\hline Mean WTP & 21.72 & 7.41 \\
& $(22.68)$ & $(14.90)$ \\
\hline$N$ & 95 & 48 \\
\hline
\end{tabular}

Note: Standard errors in brackets. Estimates are based on the corresponding columns in Table 3. 
Table 6. Water Quality Descriptive Statistics

\begin{tabular}{|c|c|c|c|c|c|c|}
\hline & \multicolumn{3}{|c|}{ Fecal coliform $(\mathrm{cfu} / 100 \mathrm{~mL})$} & \multicolumn{3}{|c|}{ \# cases of diarrhea per person } \\
\hline & Mean & Std. Dev & $\begin{array}{c}\text { Spearman } \\
\text { Rank } \\
\text { Correlation } \\
\text { Coefficients }\end{array}$ & Mean & Std. Dev & $\begin{array}{c}\text { Spearman } \\
\text { Rank } \\
\text { Correlation } \\
\text { Coefficients }\end{array}$ \\
\hline \multicolumn{7}{|l|}{$\begin{array}{l}\text { Water Quality } \\
\text { Perceptions }\end{array}$} \\
\hline Unknown/Unsure & 38.36 & 91.87 & -0.09 & 0.28 & 0.40 & $0.18^{*}$ \\
\hline Very dirty & 6.33 & 9.29 & -0.05 & 0.28 & 0.25 & 0.10 \\
\hline Dirty & 82.00 & 169.48 & 0.05 & 0.13 & 0.18 & -0.06 \\
\hline Clean & 33.61 & 81.05 & 0.06 & 0.16 & 0.27 & -0.07 \\
\hline Very clean & 74.25 & 138.81 & 0.01 & 0.04 & 0.11 & $-0.17 *$ \\
\hline
\end{tabular}

Note: The number of cases of diarrhea per person in a household over a one-week period. * indicates statistical significance at the $10 \%$ level for the Spearman Rank Correlation Coefficient. 
Figure 1. Locations of Sample Households, Public Water Tanks and Water Testing Lab in San Mateo Ixtatán, Guatemala

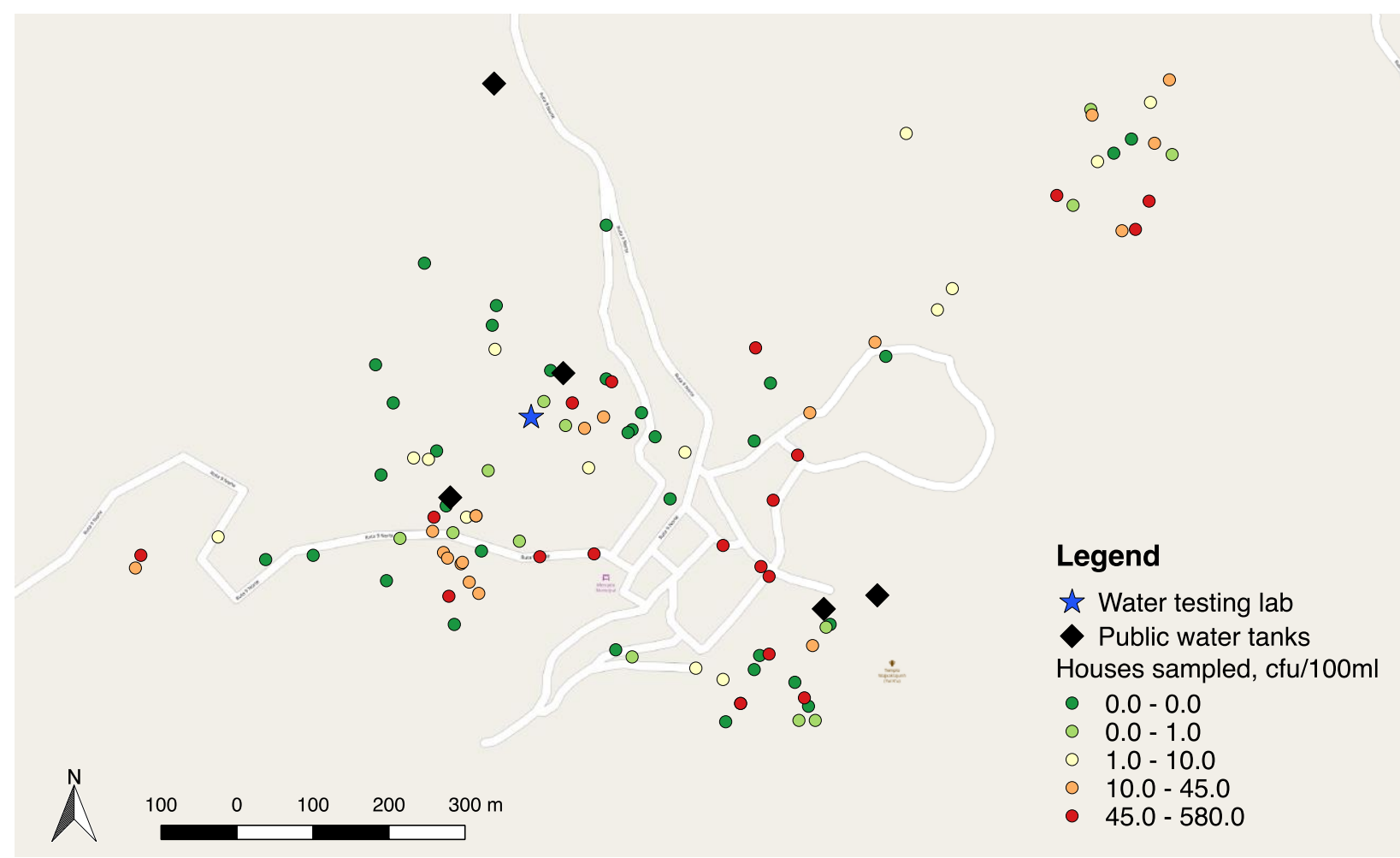

Note: The colors indicate different ranges of fecal coliform measurements (cfu/100ml) from water quality sample from the home of each household. 
Figure 2. Mean Fecal Coliform Measurements by Water Quality Perception Category

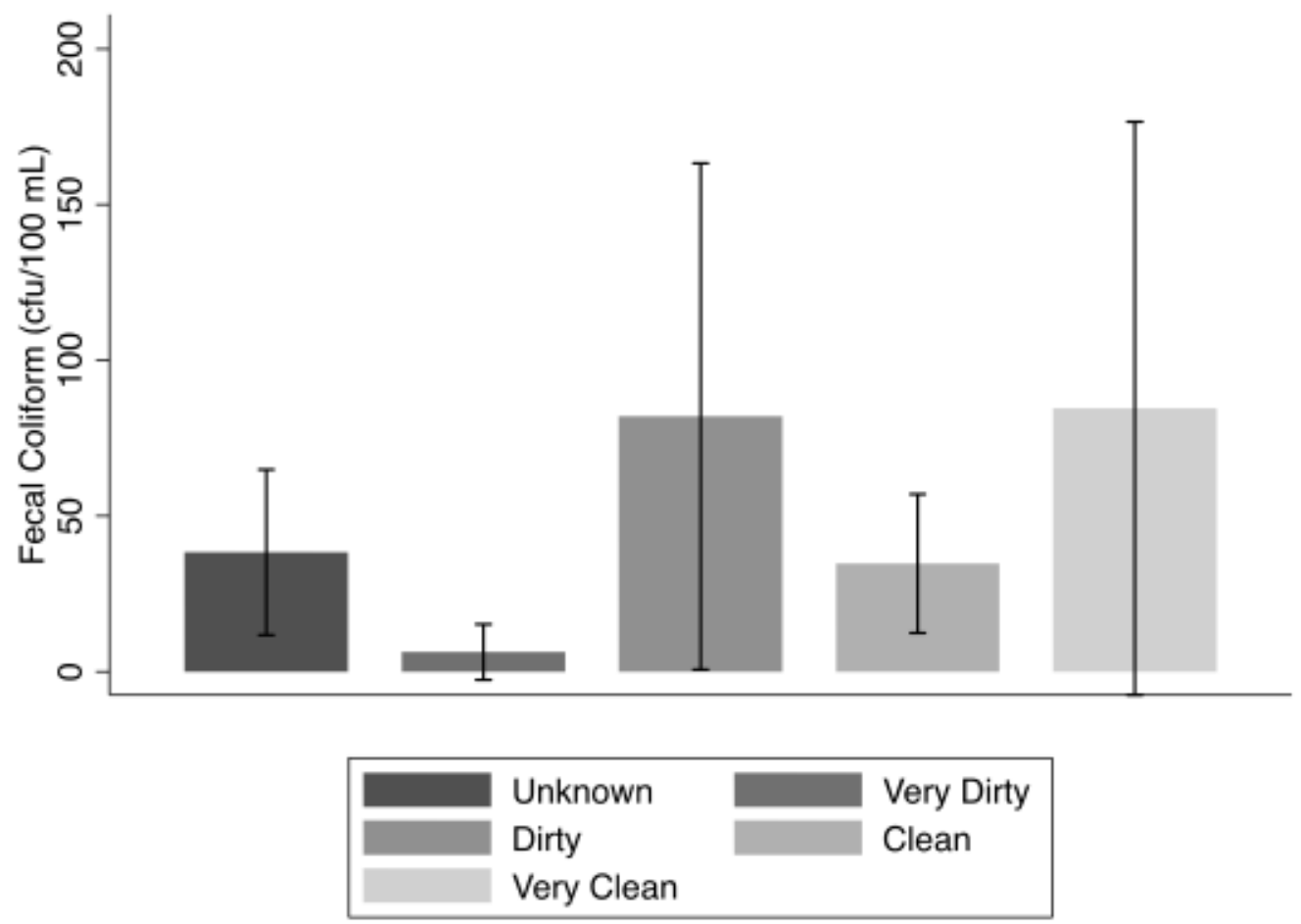

Note: Bar chart with confidence intervals at $90 \%$. Each bar reports the mean measured levels of fecal coliform by the household's perceptions of their own drinking water cleanliness. 
Figure 3. Mean Number of Cases of Diarrhea by Water Quality Perceptions Category

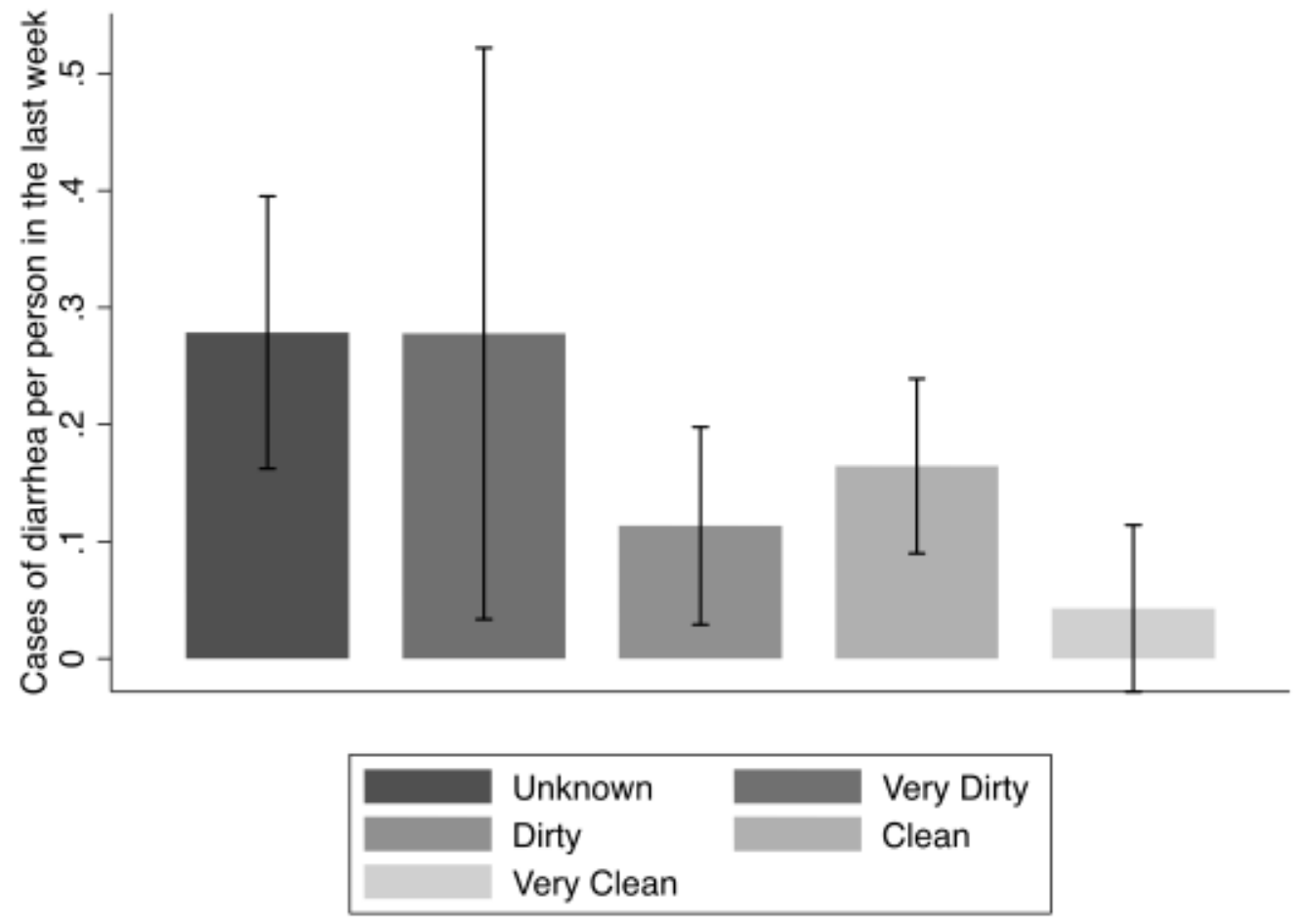

Note: Bar chart with confidence intervals at $90 \%$. Each bar reports the mean cases of diarrhea per person in a household by the household's perceptions of their own drinking water cleanliness. 
Appendix:

To supplement the analysis in the main text we provide additional regression results to demonstrate the robustness of the results. First, we report results of regressions with minimum controls in Table 1A, which establishes the same results in the main text but without the additional co-variates as controls.

Table 1A. Basic Logit Regression Results

\begin{tabular}{|c|c|c|c|c|}
\hline & \multicolumn{2}{|c|}{ Water Filter } & \multicolumn{2}{|c|}{ Water Test } \\
\hline & $\begin{array}{l}\text { Full sample } \\
\text { (1) }\end{array}$ & $\begin{array}{l}\text { Full sample } \\
\text { (2) }\end{array}$ & $\begin{array}{l}\text { Full sample } \\
\text { (3) }\end{array}$ & $\begin{array}{l}\text { Full sample } \\
\text { (4) }\end{array}$ \\
\hline \multirow[t]{2}{*}{ Price } & $-0.009 * *$ & $-0.009 * *$ & $-0.007 *$ & -0.007 \\
\hline & $(0.004)$ & $(0.004)$ & $(0.004)$ & $(0.004)$ \\
\hline \multicolumn{5}{|c|}{ Water Quality Perceptions } \\
\hline \multirow[t]{2}{*}{ Very clean } & - & $-1.609^{*}$ & - & 0.403 \\
\hline & - & $(0.886)$ & - & $(0.804)$ \\
\hline \multirow[t]{2}{*}{ Constant } & $1.095 * *$ & $1.311 * * *$ & 0.406 & 0.361 \\
\hline & $(0.433)$ & $(0.459)$ & $(0.412)$ & $(0.421)$ \\
\hline$N$ & 95 & 95 & 95 & 95 \\
\hline Pseudo R-squared & 0.0455 & 0.060 & 0.022 & 0.024 \\
\hline \multirow[t]{2}{*}{ Mean WTP } & 159.09 & 148.46 & 125.62 & 127.66 \\
\hline & $(51.48)$ & (41.57) & $(49.65)$ & $(52.51)$ \\
\hline
\end{tabular}

Note: Standard errors in brackets. ***,**,* indicate statistical significance at the $1 \%, 5 \%$, and $10 \%$ level. The mean WTP is calculated based on logit results in this table.

In Table $2 \mathrm{~A}$ we mimic the regressions from the Table 3 in main text, but include an interaction of the Price and water quality perceptions of the Very Clean category. We have 
suppressed the other covariates for brevity and find that the interaction is not statistically significant. In column 2 of Table $2 \mathrm{~A}$ we cannot identify the interaction term due to a collinearity problem with other covariates.

Table 2A. Logit Regression Results with Interaction

\begin{tabular}{lcccc}
\hline & \multicolumn{2}{c}{ Water Filter } & \multicolumn{2}{c}{ Water Test } \\
\hline & $\begin{array}{c}\text { Full sample } \\
(1)\end{array}$ & $\begin{array}{c}\text { Definitely sure } \\
\text { subsample } \\
(2)\end{array}$ & $\begin{array}{c}\text { Full sample } \\
(3)\end{array}$ & $\begin{array}{c}\text { Definitely sure } \\
\text { subsample } \\
(4)\end{array}$ \\
\hline $\begin{array}{l}\text { Very clean Water Quality } \\
\text { Perceptions * Price }\end{array}$ & -0.008 & - & -0.021 & 0.075 \\
& $(0.834)$ & - & $(0.026)$ & $(0.062)$ \\
\hline
\end{tabular}

Note: Standard errors in brackets.

In Table 3A we provide a specification which interacts the Definitely Sure response with the Price variable to estimate hypothetical bias. We find similar results of the WTP for each water quality product presuming significance of the point estimates, though the individual estimates of the coefficients become more statistically weak.

Table 3A. Other Specifications for Hypothetical Bias

\begin{tabular}{lcc}
\hline & $\begin{array}{c}\text { Water Filter } \\
(1)\end{array}$ & $\begin{array}{c}\text { Water Test } \\
(2)\end{array}$ \\
\hline Price & -0.004 & -0.005 \\
& $(0.008)$ & $(0.008)$ \\
& & -0.692 \\
Definitely Sure & 1.708 & $(1.047)$
\end{tabular}




\begin{tabular}{lcc} 
Definitely Sure*Price & -0.018 & -0.012 \\
& $(0.012)$ & $(0.011)$ \\
\hline$N$ & 95 & 95 \\
Pseudo $R$-squared & 0.2518 & 0.2008 \\
\hline
\end{tabular}

Note: Standard errors in brackets.

In Table 4A and 4B we run a 2SRI model which uses the distance to the nearest water tank as an instrument in column (1) of Table 4B and both the distance to the nearest water tank and the measure of fecal coliform as instruments in column (2) of Table 4B. Both the first stage and second stage are reported below.

Table 4A. Two-stage Residual Inclusion Regression Results: First Stage

\begin{tabular}{lcc}
\hline \multicolumn{3}{c}{ First Stage: Water Quality Perceptions } \\
\hline & -0.236 & $(0.966)$ \\
\hline Head of household & -1.110 & $(0.924)$ \\
Female & -0.002 & $(0.031)$ \\
Age & & \\
Water Treatment & 0.495 & $(0.942)$ \\
Boil water & & \\
Health & -9.567 & $(6.964)$ \\
\# cases of diarrhea per house & & \\
Water Quality Measurement & 0.008 & $(0.006)$ \\
Fecal coliform & 0.002 & $(0.002)$ \\
Distance to Water Tank & -1.594 & $(1.718)$ \\
Constant & \multicolumn{2}{c}{94} \\
\hline N & & \\
Pseudo R-squared & & \\
\hline
\end{tabular}

Table 4B. Two-stage Residual Inclusion Regression Results: Second Stage 


\begin{tabular}{|c|c|c|c|c|}
\hline \multirow[b]{3}{*}{ Price } & \multicolumn{4}{|c|}{ Water Filter } \\
\hline & \multicolumn{2}{|c|}{ (1) } & \multicolumn{2}{|c|}{$(2)$} \\
\hline & $-0.015^{* *}$ & $(0.006)$ & $-0.013 * *$ & $(0.006)$ \\
\hline \# in household & 0.007 & $(0.119)$ & -0.039 & $(0.114)$ \\
\hline Head of household & -0.065 & $(0.594)$ & -0.091 & $(0.581)$ \\
\hline Female & $-1.899 * *$ & $(0.924)$ & $-2.026 * *$ & $(0.876)$ \\
\hline Age & -0.019 & $(0.020)$ & -0.019 & $(0.019)$ \\
\hline Primary education & -0.210 & $(0.835)$ & -0.031 & $(0.781)$ \\
\hline Middle school ed. & 0.175 & $(0.925)$ & 0.497 & $(0.858)$ \\
\hline Secondary school ed. & $2.325^{*}$ & $(1.259)$ & $2.622 * *$ & $(1.252)$ \\
\hline Post-secondary school ed. & 0.991 & $(1.071)$ & 1.460 & $(0.988)$ \\
\hline \multicolumn{5}{|l|}{ Water Treatment } \\
\hline Boil water & 0.645 & $(0.742)$ & 0.651 & $(0.700)$ \\
\hline \multicolumn{5}{|l|}{ Water Quality Perceptions } \\
\hline Very clean & -4.888 & $(6.230)$ & $-11.405 * *$ & $(5.122)$ \\
\hline \multicolumn{5}{|l|}{ Health } \\
\hline \# cases of diarrhea per & -1.039 & $(1.086)$ & -1.985 & $(1.012)$ \\
\hline \multicolumn{5}{|l|}{ Water Quality Measurement } \\
\hline Fecal coliform & -0.009 & $(0.006)$ & - & - \\
\hline X-hat & 0.671 & $(2.020)$ & $2.845^{*}$ & $(1.610)$ \\
\hline Constant & $3.965^{* *}$ & $(1.921)$ & $4.328 * *$ & $(1.817)$ \\
\hline$N$ & \multicolumn{2}{|c|}{94} & \multicolumn{2}{|c|}{94} \\
\hline Pseudo R-squared & \multicolumn{2}{|c|}{0.2580} & \multicolumn{2}{|c|}{0.2121} \\
\hline
\end{tabular}

Note: $z$-statistics are reported in brackets. X-hat is the residual from the first stage in Table 4A. In both models (1) and (2) we use the results of bivariate first stage estimates.

We report in Table 5A the results of using the covariate of "Definitely Sure" as a control versus the estimates using the subsample of "Definitely Sure" respondents. We find nearly identical estimates in both methods. 
Table 5A. Mean Willingness to Pay (Currency: Quetzal)

\begin{tabular}{lrccc}
\hline & \multicolumn{2}{c}{ Water Filter } & \multicolumn{2}{c}{ Water testing service } \\
\hline & $\begin{array}{c}\text { Definitely sure } \\
\text { subpopulation }\end{array}$ & $\begin{array}{c}\text { Full Sample and } \\
\text { Includes "Definitely } \\
\text { Sure" as covariate }\end{array}$ & $\begin{array}{c}\text { Definitely sure } \\
\text { subpopulation }\end{array}$ & $\begin{array}{c}\text { Full Sample and } \\
\text { Includes "Definitely } \\
\text { Sure" as covariate }\end{array}$ \\
\hline Mean WTP & 134.95 & 134.64 & 60.31 & 66.92 \\
& $(34.32)$ & $(35.89)$ & $(14.23)$ & $(19.68)$ \\
\hline$N$ & 48 & 95 & 55 & 92 \\
\hline
\end{tabular}

Note: Standard errors in brackets. Estimates are based on logit regression results from corresponding columns in Table 3 and a new specification where instead of splitting the sample we estimate the full sample and include `Definitely Sure responses as covariates. 